\title{
Adaptation to Climate Change and Regional Planning: A Scrutiny of Sectoral Instruments
}

\author{
Antonio Ledda ${ }^{1, * \mathbb{D}}$, Elisabetta Anna Di Cesare ${ }^{2}$, Giovanni Satta ${ }^{3}$, Gianluca Cocco ${ }^{3}$, \\ Giovanna Calia ${ }^{2}$, Filippo Arras ${ }^{3}$, Annalisa Congiu ${ }^{3}$, Emanuela Manca ${ }^{3}$ and \\ Andrea De Montis 1,2 (D) \\ 1 Department of Agricultural Sciences, University of Sassari, viale Italia 39, 07100 Sassari, Italy; \\ andreadm@uniss.it \\ 2 Department of Civil and Environmental Engineering and Architecture, University of Cagliari, via Marengo 2, \\ 09123 Cagliari, Italy; elisabetta.dicesare@unica.it (E.A.D.C.); giovannacalia@live.it (G.C.) \\ 3 Regione Autonoma della Sardegna, Direzione Generale della Difesa dell'Ambiente, via Roma 80, \\ 09123 Cagliari, Italy; giosatta@regione.sardegna.it (G.S.); giacocco@regione.sardegna.it (G.C.); \\ farras@regione.sardegna.it (F.A.); ancongiu@regione.sardegna.it (A.C.); \\ emamanca@regione.sardegna.it (E.M.) \\ * Correspondence: antonioledda@uniss.it; Tel.: +39-079-229-240
}

Received: 15 April 2020; Accepted: 5 May 2020; Published: 7 May 2020

\begin{abstract}
Adaptation to climate change means adjustment of human and natural systems to climatic actual or expected events, in order to minimize damage or maximize benefit. Adaptation implies involvement, coordination, and cooperation of different actors and sectors. Multi-actor collaboration usually characterizes the drafting of regional plans, which act as bridges between national and local administrative levels. Regional administrations address resilience issues, through spatial planning processes. This study focuses on the regional plans adopted by the Autonomous Region of Sardinia (Italy), south European Mediterranean region, an area that will be negatively affected by climate change in the coming decades. We aim at proposing a method for scrutinizing regional plans related to spatial planning issues, by using criteria rooted in the scientific literature and adaptation strategies. We found out that (i) the scientific literature did not sufficiently address the role of regional plans in the context of adaptation to climate change and (ii) the method proposed and applied in this study highlights whether some key adaptation issues are included in the plans, and might make aware planners and policy makers of basic information concerning the interplay 'regional planning vs. adaptation to climate change'.
\end{abstract}

Keywords: climate change; adaptation to climate change; spatial planning; scrutiny of regional plans; content analysis

\section{Introduction}

The increase of the Earth's surface average temperature has characterized recent decades [1,2]. Extreme and more frequent weather events and the rising sea level are affecting the lifestyles and safety of the human population, as well as the ecosystem's balance [2]. Thus, climate change has become an increasingly relevant and worrying phenomenon worldwide and could not be immediately stopped even if the emission of greenhouse gases into the atmosphere was interrupted today [3]. Although mitigation is crucial to limit long-term impacts due to climate change [4], effective short term-solutions are necessary. Hence, attention to adaptation has increased over recent years [2,5]. Adaptation strategies are acknowledged as a complement to mitigation measures [6]. Adaptation to climate change (ACC) means adjustment of human and natural systems to climatic actual or expected 
events, in order to minimize damage or maximize benefit [7]. ACC can be 'autonomous', as voluntary reaction of private actors and public bodies to climate change, or 'planned', which consists of policies, plans and measures designed to increase the resilience of society [8]. The planned adaptation has been acknowledged by scholars as matter of multi-level governance [8,9]. ACC implies cascading decisions, which involve individuals and public bodies, from local to national scales [10]. Scholars acknowledged that effective ACC could be achieved through both multi-level and multi-sectoral approaches [11,12], although the effectiveness of the multi-level governance in addressing the human-ecological systems cannot be guaranteed [13]. According to Dannevig and Aall [8], excluding a few scholars, academic research has dealt with the regional adaptation governance with limited attention, while more attention has been paid to national and local governance.

Over the years, as a response to the changing climate, adaptation strategies and plans have been released in Europe [14]. In 2013, the European Commission adopted the European Union strategy (EU strategy) on ACC [5], which aims at making the European member states more climate-resilient. The EU strategy stresses the need to adopt adaptation measures at all levels, from national to regional level and highlights that the Mediterranean basin is a particularly vulnerable area with respect to climate change [5]. The EU strategy also remarks on the necessity to improve the coordination among the levels to respond to climate change, and "achieve coordination and coherence at the various levels of planning and management" [5] through national adaptation strategies. In 2015, the Italian Ministry of the Environment and Protection of Land and Sea (MEPLS) adopted the National Climate Change Adaptation Strategy (NCCAS) [15], and released a draft of the National Climate Change Adaptation Plan (NCCAP) in 2017 [16]. In 2019, the Autonomous Region of Sardinia (acronym ARS, Italy) adopted the regional strategy for ACC (RSACC), which has paved the way for making the region more resilient to extreme weather events.

The regional plans should be consistent with the framework defined by RSACC. In this vein, spatial planning can play a crucial role for encouraging ACC [17-20]. 'Spatial planning' can be defined in several ways [21]. According to Davoudi et al. [19], 'spatial planning' implies "actions and interventions that are based on 'critical thinking about space and place' [that] involves not only legislative and regulatory frameworks for the development and use of land, but also the institutional and social resources through which such frameworks are implemented, challenged and transformed" [19] (p. 14).

The integration of adaptation objectives in regional and local contexts could be effectively implemented through spatial planning, in order to address budget constraints and develop synergies [22]. The regional planning tools are usually designed through multi-actor collaboration and might be a reference framework to define effective adaptation measures at sub regional level, i.e., for addressing municipal master plans to making local landscapes and territories more resilient to climate changes. Although the regional plans are relevant to local planning and might be key to link national and regional adaptation principia and strategies to local adaptation measures, we identified a research gap in scientific literature that addresses ACC in the context of regional spatial planning. This study aims at filling this research gap, as we aim at scrutinizing a set of regional plans closely related to spatial planning issues, with respect to the attitude toward integrating the concepts of ACC. We assess the performance of the regional plans, with respect to criteria inspired by the principles stressed in RSACC [23].

This paper is structured to provide the readers with answers to the following research questions $\left(\mathrm{RQ}_{\mathrm{s}}\right)$ : is it possible to construct a method supporting the assessment of the attitude of regional plans to integrating the issues of $A C C\left(R_{1}\right)$ ? What are the main results of the application of this method to the case of Sardinia, Italy $\left(\mathrm{RQ}_{2}\right)$ ? $\mathrm{RQ}_{1}$ is methodological and implies an accurate review of the scientific literature, which is aimed at defining an analytical framework for the assessment of the tendency of the regional plans to consider the concepts of $A C C$. $R Q_{2}$ is operational, as it attains the application of the method to the scrutiny of regional plans adopted in Sardinia, with respect to their focus on ACC.

The paper unfolds as follows. In the next Section 2, we report on adaptation strategies and plans across the European Union and focus on the Italian context. In Section 3, we summarize scientific 
works concerning the relevance of spatial planning for ACC. We stress that the purpose of the literature review in Section 3 is not to provide an extensive summary on spatial planning and ACC, but to provide the reader with an overview of the importance of spatial planning in the realm of ACC by pointing out some important issues. In Section 4, we describe the method proposed to figure out if, and to what extent, selected regional plans closely related to spatial planning consider ACC. In Section 5, we present the results while in Section 6, we discuss the findings. Finally, in Section 7, we focus on the concluding remarks, by stressing the contribution of this study to the advancement of scientific research.

\section{Adaptation Strategies and Plans across EU}

In 2013, the European Commission adopted a strategy on adaptation to climate change (EU strategy), which aims at making the European context more climate resilient [5]. The EU strategy focuses on promoting (i) action by Member States, (ii) more informed decision-making, and (iii) adaptation in key vulnerable sectors. Although that document is not a binding regulatory act for the Member States (such as, for example, European Directives and Regulations), it requires that each Member State defines a national adaptation strategy (Figure 1).

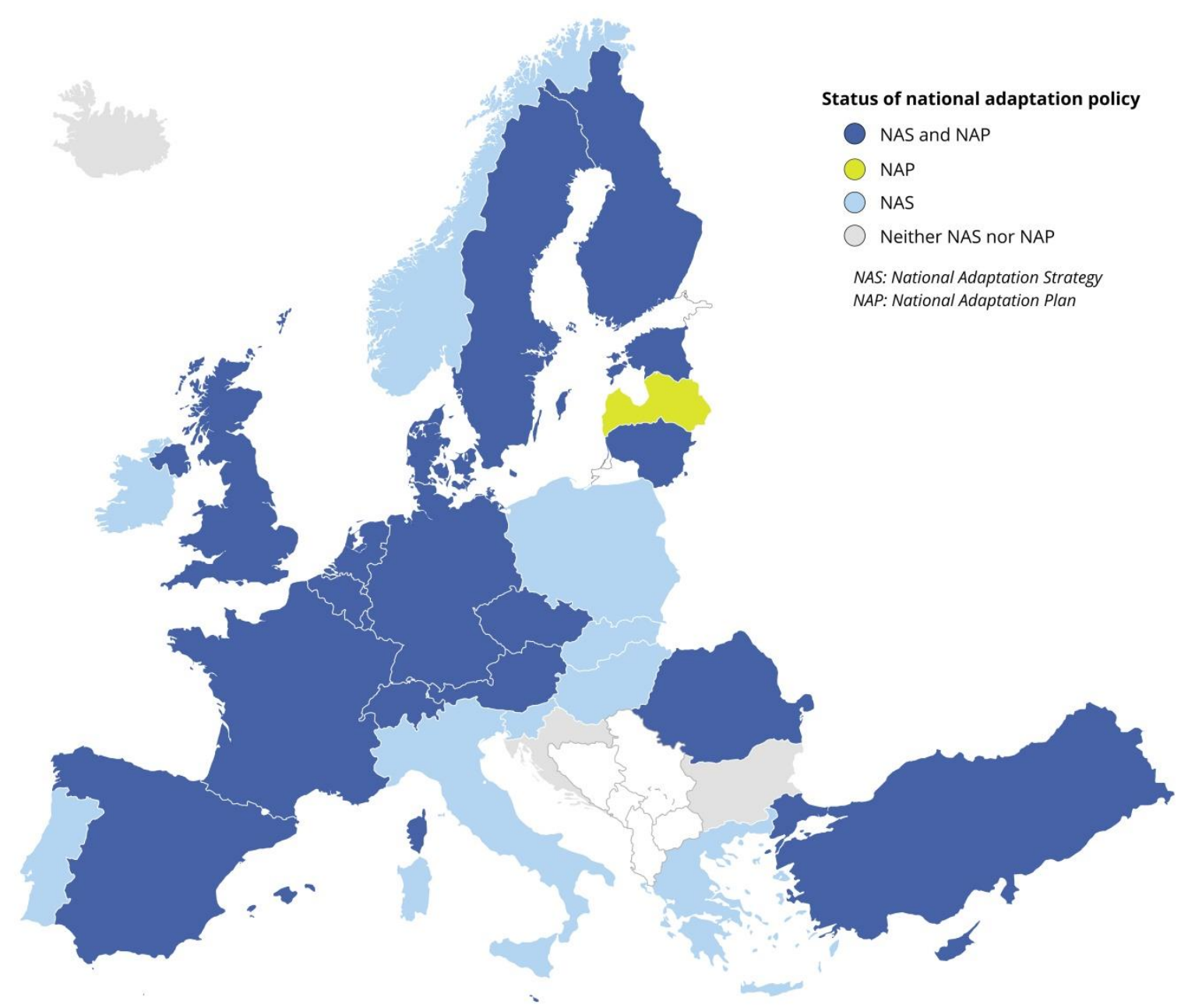

Figure 1. Overview of National Adaptation Strategies and Plans in EU Member and non-Member states. Source: European Environment Agency (EEA) [14]. Figure created on 31 July 2019 and published on 3 December 2019. Original image edited by the Authors. 
As Figure 1 illustrates, the majority of states adopted both national adaptation strategy (NAS) and national adaptation plan (NAP). Another cluster of states, including Italy, has adopted only a NAS. In Italy, in 2015 the Ministry for Environment, Land and Sea Protection approved the NSACC (equivalent to NAS). The NSACC describes the main impacts of climate change on socio-economic and natural sectors and proposes adaptation measures. The NCCAP (equivalent to NAP) is the implementation tool of the NSACC, and has been submitted to the Italian Environment and Energy Commission for consultation in the State-Regions Conference, thus it is not in force yet.

Both NSACC and NCCAP define a reference framework for regional and local strategies, and adaptation measures. NCCAP [16] acknowledges gray, green and soft adaptation measures. Gray measures include technological and engineering solutions, green ones consist of ecosystem-based approaches, while the soft ones include management, legal and political approaches (including the governance system) to ACC. According to NSACC [15], the effects of climate change in the European Mediterranean region will be particularly negative in the coming decades. These effects, coupled with those due to anthropogenic pressure on natural resources, make this area one of the most vulnerable in Europe [15].

The EU strategy points out that adaptation measures have to be defined across national, regional, and local levels [5], and the regions play a key role as stressed by national documents concerning adaptation processes [22]. NSACC includes general principia, state of knowledge on sectoral impacts and vulnerabilities, and cross-sectoral aspects concerning adaptation and risk management. It also includes actions proposed for achieving ACC. In turn, NCCAP defines actions tailored for six terrestrial and two marine homogeneous climatic macro-regions, which consist of parts of the national territory showing similar climatic conditions in the 1981-2010 time span ([16]; Figure 2). The geographical pattern of the macro-regions reflects different climatic scenarios, which require specific adaptation rationales, planning, policies, and measures.

According to Figure 2, Sardinia belongs to the macro-region 6 'Islands and south of Italy'. In 2019, ARS adopted the Regional Adaptation to Climate Change Strategy (RACCS), which is consistent with NSACC and NCCAP. The drafting of RACCS has involved several expertise including academics, climate scholars, and spatial planners and has required a challenging coordination among research groups and regional institutions.

The RACCS includes six chapters attaining: (i) description of risks due to climate change in Sardinia, (ii) assessment of the regional adaptive capacity, (iii) assessment of impacts due to climate change and of risk-proneness for specific sectors, (iv) options and priorities of adaptation strategies to climate change, (v) governance models for the implementation of adaptation measures, and (vi) description of the Regional Environmental Information System. As for the purpose of this study, the analysis of the regional plans and programs was presented in chapter five and was key to define tailor-made governance models for Sardinia [23]. 


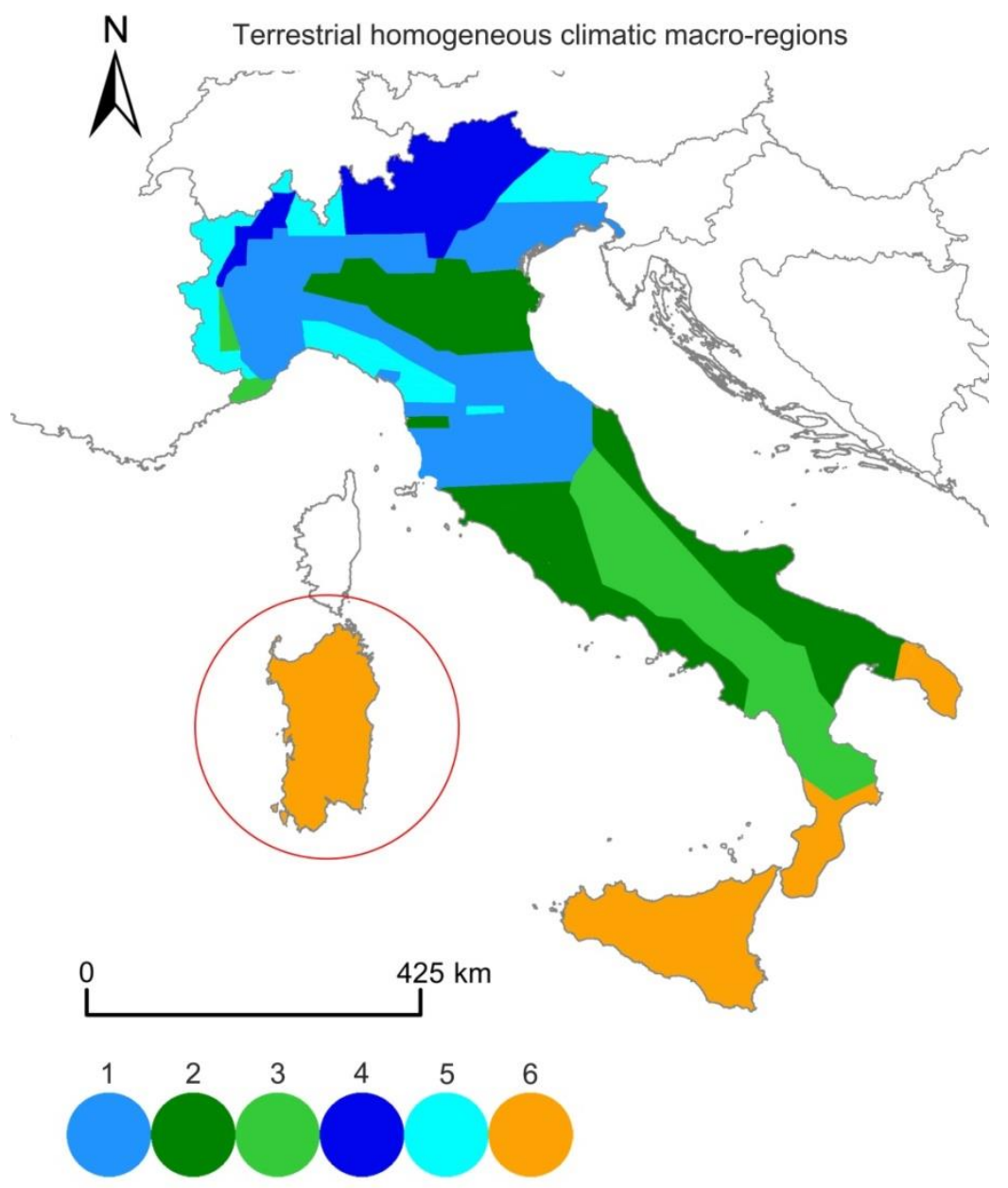

Figure 2. The terrestrial homogeneous climatic macro-regions of the Italian National Climate Change Adaptation Plan. Macro-region 1: Prealps and Northern Apennines; macro-region 2: Pianura Padana, Adriatic upper side, and coastal areas of central-southern Italy; macro-region 3: Central-southern Apennines; macro-region 4: Alpine area; macro-region 5: Northern Italy; macro-region 6: Islands and south of Italy. Sardinia (marked by the red circle) belongs to the macro-region 6. Elaboration of the Authors of the original image retrieved from the Italian NCCAP ([16] (p. 19)). More precise details in the original image.

\section{Literature Review on Spatial Planning for Adaptation to Climate Change}

Spatial planning implementation involves a range of agencies belonging to local, national, and international level, according to frameworks that depend on custom and planning tradition [21]. Generally, the EU Member States show three levels of government that play a role in spatial planning [21]. In Italy, four administrative levels are acknowledged: State, region, province, and municipality [24]. The State releases national sector plans very rarely, as planning competences have been transferred to the lower level administrative bodies. Regions, provinces, and municipalities manage and plan their development through a variety of tools showing three different functions: coordination, operative regulation (i.e., land-use zoning), and actuation. Planning instruments show variable denomination. Usually, regional and provincial administrations design tools aiming at addressing the development of large portions of land through general dispositions. These bodies deliver coordinator territorial plans or regional landscape plans (at the regional level), and the provincial coordinator territorial plans (at the provincial level). Municipalities express regulation on the right of modifying the territory, according to municipal master plans. They also indicate how a given piece of land will be transformed through actuation plans that describe the details of land development [25-29]. 
According to Gaugitsch et al. [21], the visionary approach (general aims, for example) belongs to most national planning tools, the "strategic or framework-setting instruments" characterize the regional level, and the regulative planning tools are typical of the local level.

As for the regional level, in Sardinia the Regional Landscape Plan (RLP) is the territorial governance instrument that aims at preserving, protecting, enhancing, and handing down the environmental, historical, cultural and settlement identity of the territory to future human generations [30]. RLP is consistent with the principia and contents of the European Landscape Convention [31,32], and its objectives include protection of cultural and natural landscapes and regional territory, and the promotion of sustainable development [30]. In Italy, it is acknowledged as a latest generation landscape planning tool [33]. The RLP is framework for both landscape and territorial planning tools at regional and local level.

According to Adger et al. [10], ACC involves a network of private and public actors across different levels. In Italy, national, regional and local plans are usually drawn up through multi-actor collaboration, according to multi-level and multi-sectoral approaches, which can be relevant with respect to ACC. Spatial planning plays an essential role in addressing climate change [34] and in the context of ACC [17-20]. Bruneniece and Klavins [17] stress the key relevance of regional and local governmental bodies for ACC. Indeed, such institutions are usually holders of accurate information concerning both local contexts and conditions able to promote or hinder environmental changes. However, the validity of regional and land use plans vary in the 10-15 years range, while a time span of 50-100 years can characterize the climate projections [35]. As Fröhlich and Knieling [35] point out, the time horizons of planning tools differ from those adopted in climate changes modulization. This is significant for the democratic legitimacy of intergenerational policies [35], since the climate projections timeframe exceeds both spatial planning and electoral cycles.

Biesbroek et al. [36] focus on the adaptation-mitigation dichotomy and the role of spatial planning as tools for integrating adaptation and mitigation issues into spatial planning practices. The authors report on differences in approaching climate change, according to three factors that contribute in reinforcing the adaptation-mitigation dichotomy: temporal dimension, administrative scales, and stakeholders involvement [36]. According to Hurlimann and March [18], spatial planning has a relevant role in the context of ACC. They discuss six reasons why spatial planning can deal with adaptation including, inter alia, capacities of managing collective and public issues and its characteristic of thinking and acting across various scales [18]. According to Davoudi et al., the sub-national government takes on an important role in the formulation and implementation of spatial planning policies [19]. Wilson underlines the critical role of local spatial planning as means to promote ACC [20]. The author focuses on adaptation and the task of spatial planning and development plans in the UK, and points out that ACC has been considered more in the context of flood risk than in other planning contexts as consequence of political willingness. Gill et al. [37] discuss the potential of green infrastructure (GI) as resource to adapt urbanized areas to climate change and suggest the need to stress the role of GI in ACC in planning and policies tools at all levels.

Subnational level spatial planning tools are key to mainstreaming ACC. The importance of spatial planning has been stressed by scholars. However, we found that the scientific literature did not sufficiently address ACC in the context of regional plans closely related to spatial planning. In particular, there is a research gap concerning studies that proposed and applied methods for scrutinizing regional plans against a set of criteria rooted in literature and adaptation strategies, and that are able to stress some key adaptation issues of such planning tools in terms of ACC.

\section{Materials and Methods}

This section is split in two subsections. In the first subsection, we select a set of regional plans. In the second one, we explain the criteria-based method used to analyze the plans. The basic criteria ground on the contents of the EU strategy and the Italian NSACC, and on the scientific literature. 


\subsection{Defining the Sample}

England et al. [11] proposed and applied a research method articulated in several steps, which included the scrutiny of policy documents concerning Water Policy, Agricultural Policy, National Development Plans, Climate Change, National Adaptation Action Plan, and so on, of Malawi, Tanzania, and Zambia (Africa). They assessed: (i) "whether adaptation was being considered or not; (ii) how it was being treated; and (iii) whether climate change adaptation statements were coherent with the other documents assessed" [11] (p. 2061). Inspired by this approach, we propose and apply a modified qualitative approach. We performed a document analysis according to the following steps: (i) collection of the main strategic regional plans related to spatial planning, and presenting the relevant connections between sectoral issues and ACC; (ii) document analysis by using specific criteria (described in the next subsection), in order to assess if, and to what extent, ACC concepts have been included in the regional plans.

Table 1 reports on the set of six regional plans scrutinized.

Table 1. The regional plans considered in this study. The first column indicates the plan analyzed, the second one the year of approval, the third one summarizes some noteworthy aspects of the plans, while the last column concerns the references.

\begin{tabular}{|c|c|c|c|}
\hline Plan & Year & Description & Reference \\
\hline $\begin{array}{l}\text { Regional landscape plan (RLP, Piano } \\
\text { paesaggistico regionale, in Italian) }\end{array}$ & 2006 & $\begin{array}{l}\text { The RLP is consistent with the contents of the European } \\
\text { landscape convention. The RLP steers local plans toward } \\
\text { environmental and landscape protection and urban quality. }\end{array}$ & [30] \\
\hline $\begin{array}{l}\text { Hydrogeological System Plan } \\
\text { (HSP, Piano stralcio } \\
\text { per l'assetto idrogeologico) }\end{array}$ & 2006 & $\begin{array}{l}\text { The HSP rules the regional context and provides operational } \\
\text { tools aiming at preventing the } \\
\text { hydro-geological risk, and preserving and defending the soil. }\end{array}$ & [38] \\
\hline $\begin{array}{c}\text { River Basin District } \\
\text { Management Plan } \\
\text { (RBDMP, Riesame e aggiornamento } \\
\text { del piano di gestione del distretto } \\
\text { idrografico della Sardegna) }\end{array}$ & 2016 & $\begin{array}{l}\text { The RBDMP is an operational tool that aims at (i) protecting } \\
\text { surface and underground water bodies and improving their } \\
\text { quality, and (ii) supporting sustainable use of water resources. }\end{array}$ & [39] \\
\hline $\begin{array}{l}\text { Regional Environmental Action } \\
\text { Plan (REAP, Piano d'Azione } \\
\text { Ambientale Regionale 2009-2013) }\end{array}$ & 2009 & $\begin{array}{l}\text { The REAP aims at implementing environmental policies } \\
\text { within the regional context. The REAP identifies four priority } \\
\text { action areas: climate change; nature, biodiversity and soil } \\
\text { protection; environment and health; sustainable use of natural } \\
\text { resources and waste management. }\end{array}$ & [40] \\
\hline $\begin{array}{l}\text { Flood Risk Management Plan } \\
\text { (FRMP, Piano di Gestione Rischio } \\
\text { Alluvioni) }\end{array}$ & 2016 & $\begin{array}{l}\text { The FRMP aims at safeguarding human life and mitigate the } \\
\text { effects of floods. The plan considers prevention, protection, } \\
\text { preparation and reconstruction measures and defines } \\
\text { structural (e.g., protection structures) and non-structural } \\
\text { (e.g., monitoring, studies) measures. }\end{array}$ & [41] \\
\hline $\begin{array}{l}\text { Regional cycling plan }(\mathrm{RCP}, \text { Piano } \\
\text { regionale della mobilità ciclistica } \\
\text { della Sardegna) }\end{array}$ & 2018 & $\begin{array}{l}\text { The RCP is a sectoral plan which aims at defining a cycling } \\
\text { mobility system at the regional scale, through the } \\
\text { identification of a regional network of cycle paths, integrated } \\
\text { with adequate provisions of cycle services and a large number } \\
\text { of intermodal hubs located along the network. }\end{array}$ & [42] \\
\hline
\end{tabular}

We select these plans, as they represent a framework for municipal master plans: their dispositions influence the design of effective actions and transformations for ACC within local spatial planning instruments. The regional plans are important by themselves and for their authority over lower administrative levels.

\subsection{Defining the Criteria}

According to Dannevig and Aall [8], excluding a few scholars, scientific research has addressed with limited attention the regional adaptation governance, while more attention has been paid on national and local governance. Dannevig and Aall [8] focused on climate change adaptation governance in Western Norway, and investigated the role of regional actors for supporting the implementation of ACC in local contexts. The authors develop the study through (i) semi-structured interviews, (ii) scrutiny of documents, and (iii) record of county governors' objections concerning municipal 
master plans. They reviewed six ongoing local planning processes. The documents analyzed by the authors included regional (county level) plans such as regional climate and energy planning tools. A framework for the assessment of the 'boundary work' inspired by Cash et al. (2003) and Hoppe and Wesselink $(2014)[43,44]$ was used in order to analyze the data. As part of their investigation, the authors found that the regional plans incorporated the issue of ACC in different ways.

Scholars focused on climate change aspects and have proposed and used criteria for scrutinizing planning tools and supplementary documents (see, for example, [45-47]). Wende et al. [45] analyzed strategic environmental assessment (SEA) reports and regional plans in Saxony (Germany) and the East of England (England, the UK), in order to investigate global climate change issues. The selected criteria were based on guidance released by the Organisation for Economic Co-operation and Development, the Canadian Environmental Assessment Agency, and other public bodies. De Montis et al. [46] proposed and applied four criteria aimed at scrutinizing SEA reports of regional plans and programmes, with the purpose of assessing their attitude at incorporating climate change adaptation issues. Recently, Lioubimtseva and da Cunhab [47] developed a comparative evaluation framework consisting of 24 indicators rooted in common guiding principles based on the academic literature and national and international guidelines, and analyzed 36 local climate change adaptation plans developed in France and the United States of America.

In this study we investigate if, and to what extent, six Sardinian regional plans have been permeated by ACC issues. We aim at providing a methodological framework that (i) allows the analysis of the regional plans according to a comparative approach, and (ii) might be replicable by other scholars. Then, we defined a set of criteria based on the scientific literature and adaptation strategies for assessing if the regional plans: (i) referred to national, European or international climate change adaptation strategies, (ii) included adaptation measures, and (iii) indicated the responsible bodies of implementation. We choose these criteria for the following reasons. As for the first criterion, the ultimate purpose of NAS is to allow adaptive practices to permeate across multiple levels of governance [9]. The European strategy [5] and the Italian NSACC [15] act as strategic frameworks for regional adaptation strategies, i.e., they inspire several sub-national plans and programmes. Thus, we ascertain if the regional plans refer to European strategy and NSACC. This is important to figure out if the regional plans are consistent with common adaptation principia and guidelines. As for the second criterion, Eisenack and Stecker defined direct adaptations those whose "purpose targeted at an impact of climate change explicit adaptations. An indirect adaptation is also called explicit, if the ultimate purpose refers to an impact of climate change. Otherwise, the action is labeled as an implicit adaptation" [48] (p. 249). In this study, we follow Donner et al. [49] and consider implicit adaptation measures those able to reduce society's vulnerability to extreme climate events, but which might have not been defined as response to climate change phenomena, while as explicit ones those measures planned as response to climate change. Ricci [50] focuses on the adaptive capacity in the peri-urban areas of Dar es-Salaam in Tanzania (East Africa). The author stresses that explicit and implicit adaptation measures characterize the autonomous adaptation practices, which could be useful when institutions have to identify potential entry points for adaptation [50]. Similarly, Eisenack and Stecker [48] point out the importance of implicit adaptations as potential entry points for explicit ACC. Dubois et al. [51] report on the findings of a research project developed in the Toulouse region (France) and involving urban practitioners (planners, engineers, landscape architects, etc.). The authors found out that the participants implicitly proposed adaptation measures that could reduce the exposure to climate risks [51]. As for the third criterion, climate change implies significant requirements in terms of governance [52]. A proper governance approach to ACC requires high level of interaction, cooperation and coordination among public and private stakeholders, and across bodies involved in several issues [52]. We mean 'governance' "as the set of decisions, actors, processes, institutional structures and mechanisms, including the division of authority and underlying norms, involved in determining a course of action" [53] (p. 315). Governance is key for defining adaptation processes [54] and new approaches are called for effective adaptation to climate change [55]. Cooperation and 
coordination among actors and sectors should contribute in solving or avoiding conflicts, and in the implementation of adaptation measures [56]. Then, the clear recognition of responsibilities is relevant to the governance of adaptation [57] and, therefore, we identified the subjects responsible for explicit adaptation measures included in the plans. In Table 2, we resume these considerations supporting the selection of our criteria.

Table 2. Criteria used to scrutinize the plans.

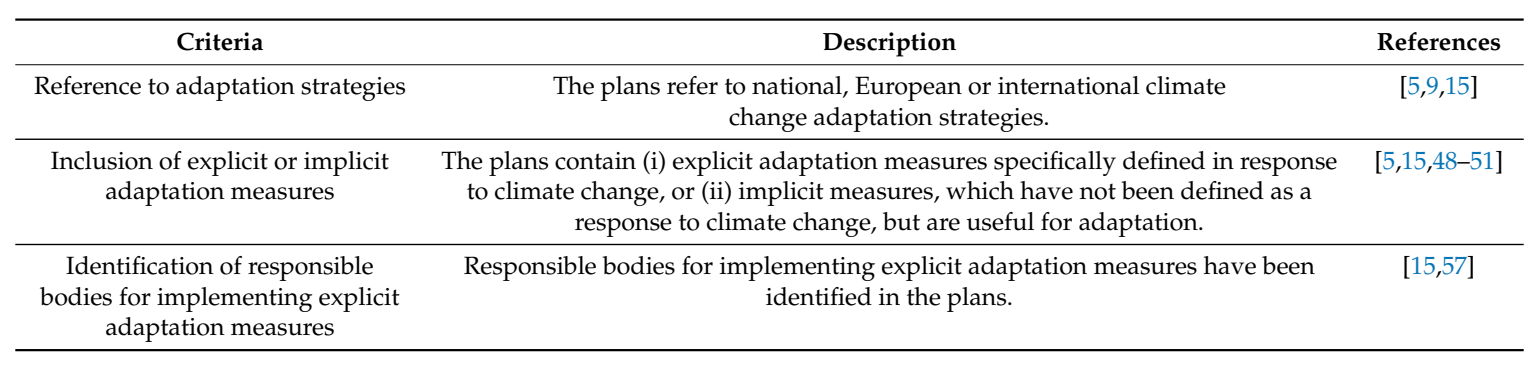

Considering that the ARS is one the few Italian regions that has adopted an adaptation strategy recently, we focused on a limited set of minimum requirements to figure out to what extend ACC is (or is not) permeated within the current regional planning scenario. We ascertained whether the criteria were met or not and reported on them through a qualitative description. Future research may consider assessment frameworks including further criteria, such as governance contexts, institutional frameworks, and geographical areas.

\section{Results}

In this section, we disclose the findings. The regional plans have been scrutinized considering the criteria listed in Table 2, namely, reference to ACC strategy, indication of adaptation measures, and indication of responsible bodies for implementation of explicit measures. We tested the applicability of the method in practice, by checking if the regional plans met the proposed criteria. Table 3 reports on the application of the method to the scrutiny of the regional plans selected in Table 1.

Table 3. Scrutiny of the regional plans: findings. The first column lists the plans, while from the second to the fifth column a check mark $(\checkmark)$ indicates if the criterion is met.

\begin{tabular}{ccccc}
\hline \multirow{2}{*}{ Plans } & \multicolumn{3}{c}{ Criteria } \\
\cline { 2 - 3 } & $\begin{array}{c}\text { Reference to } \\
\text { ACC Strategy }\end{array}$ & Indication of Adaptation Measures & $\begin{array}{c}\text { Indication of Responsible Bodies } \\
\text { for Implementation of } \\
\text { Explicit Measures }\end{array}$ \\
\cline { 3 - 4 } RLP & & Explicit & Implicit & \\
HSP & & & $\checkmark$ & $\checkmark$ \\
RBDMP & $\checkmark$ & $\checkmark$ & $\checkmark$ & $\checkmark$ \\
REAP & & & $\checkmark$ & $\checkmark$ \\
FRMP & $\checkmark$ & $\checkmark$ & & $\checkmark$ \\
RCP & $\checkmark$ & $\checkmark$ & & \\
\hline
\end{tabular}

Three plans (RBDMP, FRMP, and RCP) meet the first, second, and fourth criterion, while RLP, HSP, and REAP satisfy very weakly the requirements of our method, as they indicate only implicitly adaptation measures. In detail, FRMP and RCP clearly refer to the European and Italian adaptation strategies. The RBDMP refers to NCCAS. Then, FRMP, RCP, and RBDMP are consistent with higher level strategies or plans. In a governance system perspective, it means that adaptation principia and objectives have been transferred from higher to lower level, according to a top-down approach.

RBDMP, FRMP, and RCP include explicit adaptation measures. The RBDMP identifies measures, such as the promotion of adoption and management of high efficiency irrigation systems, planning and rationalization of water volumes per year for specific (civil, agricultural, industrial, environmental) uses, drafting and dissemination of guidelines for water saving. The FRMP is consistent with the NCCAS 
and provides prevention and protection measures aimed at increasing the resilience of the involved systems. The FRMP sets gray and soft adaptation measures. The gray adaptation measures consist of slopes stabilization, relocation of structures at risk of flooding in low-risk areas, water channeling systems, while the soft ones include planning of financial resources that should be allocated to municipalities for in-depth hydrogeological studies, and censuses of hydrogeological risk management tools, such as a Civil Protection Plans (CPP) at the municipal level. The CPP concerns executive intervention procedures aimed at dealing with any expected disaster in a specific territory [58]. Finally, the RCP primarily focuses on the health and safety of cyclists in public paths, with respect to the major threats emerging from the effects of climate change in Sardinia (e.g., heat waves). On the one hand, the RCP provides for the establishment of parking and shaded rest areas, adequately located along the routes. On the other hand, it aims at raising citizens' awareness of environmental and climate change adaptation issues through the organization of some information and promotional campaigns.

As for the implicit adaptation, both RLP and HSP report on implicit adaptation measures, which mainly consist of gray and green ones and comprehend environmental regeneration, drainage systems, safeguarding of watercourses, and preserving ecological connectivity. The REAP includes implicit adaptation measures concerning policies for water recycling and reuse, good practices for the design and management of green areas for recreational and sports use, support for drafting and implementation of District Forest Plans.

According to their respective competences, the implementation of the RBDMP is entrusted to the various regional bodies, provinces, municipalities, industrial consortia, reclamation and irrigation consortia, and water service managers. The measures defined by the FRMP have to be implemented by the Sardinian Directorate General of the Regional Agency of the Hydrographic District and municipalities. The implementation of RCP is under the responsibility of the Regional Department for Public Works, whose task is to support and coordinate the activities of design and construction of the infrastructures.

\section{Discussion}

According to the findings, three plans included references to adaptation strategies and explicit adaptation measures, and identified the responsible agency, while the remaining three plans included implicit adaptation measures, without considering ACC.

On the one hand, FRMP, RCP, and RBDMP are consistent with higher level adaptation strategies or plans. Then, according to a top-down approach, adaptation principia and objectives have been transferred from higher to lower level. In other terms, the plans met European and (or) national guidance that can be mainstreamed at local level by provinces and municipalities. Referring to Chandra and Idrisova [59] and Akhtar-Schuster et al. [60], England et al. [11] stress that coherence across policies is important in terms of greater efficiency and effectiveness, and reduction of competition for scarce budgets and resources. In Sardinia and in other contexts as well, horizontal and vertical coherence across planning tools might lead to similar benefits. Municipalities have to implement the adaptation strategies through context specific-adaptation measures. Clearly, the adaptation measures should be tailored considering also a bottom-up approach, namely, considering the local population's (public's) point of view, suggestion, and remarks. The Italian planning system usually requires the so-called 'public consultation process', which is ruled by specific legal frameworks (see, for example, [61]). On the other hand, the RLP, the only regional coordination spatial plan in force, is weakly inspired by the concepts of ACC. This scarce predisposition is very critical, as the RLP influences top-down provincial and municipal landscape and spatial planning tools.

Three plans included explicit adaptation measures. The local bodies in charge should consider such adaptation measures as sort of 'umbrella'. In fact, the design of specific adaptation measures depends on local climatic scenarios, urban characteristics, geographic location, and other constrains [51]. Three plans are devoid of explicit adaptation measures, but their contribution for increasing regional resilience, or providing a framework for specific tailored adaptation measures, might be remarkable in 
terms of ACC. As suggested in the literature $[48,50]$, implicit adaptation can be a potential entry point for explicit ACC and contribute in reducing the exposure to climatic risks [51]. RLP, HSP, and REAP include implicit gray and green adaptation measures that might contribute in making the regional context more resilient to extreme weather events. The implicit measures can be of service (or can be adapted) to various purposes, such as drainage systems for the removal of excess water, design of green areas that can counteract and reduce the heat island effect, and the hydraulic-forestry arrangements for the prevention of hydrogeological risk (landslides, floods, and soil erosion). Excess water, heat island effect, and floods are often mentioned as issues to be addressed with an adaptive approach [62-64], and next updates of the plans may adjust the implicit measures in the light of the national and regional adaptation strategy to obtain targeted explicit adaptation measures. This study did not address to what extent the identified implicit adaptation measures are relevant to ACC, but new research studies will clarify the issue.

According to Reckien and Petkova [65], scholars argue that the identification of clear responsibilities is necessary to enable effective ACC. In other terms, clear adaptation actors' roles are "crucial, in particular with regard to the protection of the most vulnerable that may lack the means to protect themselves" [65] (p. 2). Three regional plans identified the responsible agency for implementation of explicit adaptation measures. Clear responsibility about the design and implementation of adaptation measures might be an important factor, since each node of the administrative network should be known, and alerted when needed, across horizontal and vertical levels. In such a network, the nodes are the actors, who are responsible for certain adaptation measures, while the links stand for the relationships and interactions between the actors. However, we feel it is still too early to figure out if, and to what extent, this prediction is correct in the Sardinian context and this is a limitation of this study. Future studies will clarify this aspect.

The method proposed in this study has proved useful for pointing out if some key aspects of ACC are (or are not) permeated within the plans under scrutiny. It has been used in the drafting process of the Sardinian RSACC [66], one of the few regional adaptation strategies to climate change adopted in Italy so far. The regional administration leaned on the method for defining part of the governance system and clarifying to what extent the regional plans might be revised in future updates to include ACC considerations. The planning tools can enable the implementation of adaptation policies and measures, and could be reviewed accordingly [9]. Future updates of the Sardinian regional plans may consider more criteria than those proposed in this study, in order to consider new advancement in ACC research and practice. A set of new criteria might comprise the assessment of vulnerabilities and impacts due to climate change, which appear pivotal for developing regional adaptation measures [9].

\section{Conclusions}

Spatial planning addresses several issues concerning use and management of the regional land and is key for effective ACC. In this study, we selected and analyzed six regional plans closely related to spatial planning and whose contents should be translated in actions by local bodies. Indeed, the regional plans define an 'ACC framework' for municipalities, which have to transpose the regional measures within the municipal master plans.

As for the replies to the $\mathrm{RQ}_{\mathrm{s}}$ of this study, we found out a certain shortage of scientific literature concerning the role of regional plans closely related to spatial planning issues in the context of ACC. The scientific literature acknowledges a key role of spatial planning for ACC across the administrative levels and stresses that regional and local governments hold information concerning both local contexts and conditions, which can be crucial for promoting or hindering environmental changes. A critical point concerns the time horizons of planning tools, which usually differ from those adopted in climate changes modulization: the climate projection timeframe exceeds both spatial planning and electoral cycles. As for $\mathrm{RQ}_{1}$, despite some limitations, we defined a criteria based-method supporting the assessment of the attitude of the regional plans to integrating the issues of ACC. The method has been 
inspired by other research that addressed climate change under different perspectives, and incorporates their approach based on the use of criteria (or indicators).

As for $\mathrm{RQ}_{2}$, we scrutinized the plans and found out that the current regional adaptation scenario shows positive and negative aspects. As for the positive ones, the plans contain adaptation measures even implicitly, that is, measures that could contribute in increasing the regional resilience, although they were defined to achieve other goals. Furthermore, three plans identify the bodies responsible for the planned adaptation measures. As for the negative ones, the less recent regional plans should be updated, according to the regional strategy for adaptation to climate change (RSACC), which is the result of a multi-actor collaboration and includes, inter alia, guidance for mainstreaming adaptation in the current spatial planning practices.

As concluding remarks, we stress strengths and weaknesses of this study. The strengths concern the replicability of this research. We feel that the basic and simple criteria proposed and applied in this study can be used (and/or supplemented with further criteria) by other scholars or practitioners. Other similar applications could contribute in increasing knowledge and providing policy makers with clearer basic information concerning the interplay regional planning vs. ACC. Then, more informed decisions would be desirable. As for the weaknesses, in this study we use a limited set of criteria for scrutinizing the plans, and we are aware that much more criteria could be considered. In future research, we would investigate the regional plans by considering also other criteria. Secondly, we scrutinized a limited sample of regional plans: in future research studies, we aim at including other plans, also at the local level, to provide the readers with a wider panorama on regional ACC.

Despite the above limitations, the method proposed in this study has been key for the drafting of the Sardinian RSACC, which was officially adopted by the Autonomous Region of Sardinia on February 2019.

Author Contributions: Conceptualization: A.L. and A.D.M.; Methodology: A.L. and A.D.M.; Formal Analysis: A.L. and E.A.D.C.; Investigation: A.L., A.D.M., E.A.D.C. and G.C. (Giovanna Calia); Writing-Original Draft Preparation: A.L. and E.A.D.C.; Writing-Review and Editing: A.L. and A.D.M.; Supervision: A.D.M.; Data Curation: A.L., E.A.D.C., G.C. (Gianluca Cocco), G.S., F.A., A.C. and E.M. All authors have read and agreed to the published version of the manuscript.

Acknowledgments: This study has been developed and funded in the framework of the technical and scientific agreement between the Autonomous Region of Sardinia and the University of Sassari (Italy), concerning the drafting of the Regional Strategy for the Adaptation to Climate Change (SRACC). Antonio Ledda received extra-ordinary funding for research from the University of Sassari (Italy), year 2019 [Finanziamento: Fondo di Ateneo per la ricerca 2019, Università di Sassari].

Conflicts of Interest: The authors declare no conflict of interest.

\section{References}

1. Bush, M.J. Climate Change Adaptation in Small Island Developing States; John Wiley \& Sons Ltd.: Oxford, UK, 2018; ISBN 978-1-119-13284-4.

2. IPCC. Climate Change 2014: Impacts, Adaptation, and Vulnerability. Part A: Global and Sectoral Aspects. Contribution of Working Group II to the Fifth Assessment Report of the Intergovernmental Panel on Climate Change; Field, C.B., Barros, V.R., Dokken, D.J., Mach, K.J., Mastrandrea, M.D., Bilir, T.E., Chatterjee, M., Ebi, K.L., Estrada, Y.O., Genova, R.C., et al., Eds.; Cambridge University Press: Cambridge, UK; New York, NY, USA, 2014; ISBN 978-1-107-41537-9.

3. Baffo, F.; Gaudioso, D.; Giordano, F. L'Adattamento ai Cambiamenti Climatici: Strategie e Piani in Europa; Istituto Superiore per la Protezione e la Ricerca Ambientale (ISPRA): Rome, Italy, 2009.

4. Organisation for Economic Co-operation and Development. Integrating Climate Change Adaptation into Development Co-Operation: Policy Guidance; Organisation for Economic Co-operation and Development; OECD: Paris, France, 2009.

5. European Commission Communication from the Commission to the European Parliament, the Council, the European Economic and Social Committee and the Committee of the Regions. An EU Strategy on Adaptation to Climate Change /* COM/2013/0216 final *. Available online: https://eur-lex.europa.eu/legalcontent/EN/TXT/?uri=CELEX\%3A52013DC0216 (accessed on 11 April 2020). 
6. Smit, B.; Pilifosova, O.; Burton, I.; Challenger, B.; Huq, S.; Klein, R.J.T.; Yohe, G.; Adger, N.; Downing, T.; Harvey, E.; et al. Adaptation to climate change in the context of sustainable development and equity. In Climate Change 2001: Impacts, Adaptation, and Vulnerability. Contribution of Working Group II to the Third Assessment Report of the Intergovernmental Panel on Climate Change; McCarthy, J., Canziani, O., Leary, N., Dokken, D., White, K., Eds.; Cambridge University Press: Cambridge, UK; New York, NY, USA, 2001; pp. 879-912. ISBN 0-521-80768-9.

7. Salzmann, N.; Huggel, C.; Nussbaumer, S.U.; Ziervogel, G. Setting the Scene: Adapting to Climate Change -A Large-Scale Challenge with Local- Scale Impacts. In Climate Change Adaptation Strategies-An Upstream-Downstream Perspective; Salzmann, N., Huggel, C., Nussbaumer, S.U., Ziervogel, G., Eds.; Springer: Basel, Switzerland, 2016; pp. 3-15. ISBN 978-3-319-40773-9.

8. Dannevig, H.; Aall, C. The regional level as boundary organization? An analysis of climate change adaptation governance in Norway. Environ. Sci. Policy 2015, 54, 168-175. [CrossRef]

9. Biesbroek, G.R.; Swart, R.J.; Carter, T.R.; Cowan, C.; Henrichs, T.; Mela, H.; Morecroft, M.D.; Rey, D. Europe adapts to climate change: Comparing National Adaptation Strategies. Glob. Environ. Chang. 2010, 20, 440-450. [CrossRef]

10. Adger, W.N.; Arnell, N.W.; Tompkins, E.L. Successful adaptation to climate change across scales. Glob. Environ. Chang. 2005, 15, 77-86. [CrossRef]

11. England, M.I.; Dougill, A.J.; Stringer, L.C.; Vincent, K.E.; Pardoe, J.; Kalaba, F.K.; Mkwambisi, D.D.; Namaganda, E.; Afionis, S. Climate change adaptation and cross-sectoral policy coherence in southern Africa. Reg. Environ. Chang. 2018, 18, 2059-2071. [CrossRef]

12. Corfee-Morlot, J.; Kamal-Chaoui, L.; Donovan, M.G.; Cochran, I.; Robert, A.; Teasdale, P.J. Cities, Climate Change and Multilevel Governance; OECD Environmental Working Papers N 14, 2009; OECD publishing: Paris, France, 2009.

13. Di Gregorio, M.; Fatorelli, L.; Paavola, J.; Locatelli, B.; Pramova, E.; Nurrochmat, D.R.; May, P.H.; Brockhaus, M.; Sari, I.M.; Kusumadewi, S.D. Multi-level governance and power in climate change policy networks. Glob. Environ. Chang. 2019, 54, 64-77. [CrossRef]

14. EEA. Overview of National Adaptation Strategies and Plans. Available online: https://www.eea.europa.eu/ data-and-maps/figures/status-of-national-adaptation-policy-1 (accessed on 11 April 2020).

15. Ministry of the Environment and Protection of Land and Sea. Strategia Nazionale di Adattamento ai Cambiamenti Climatici (SNACC); approvata con il decreto direttoriale n. 86 del 16 giugno 2015; MEPLS: Rome, Italy, 2015.

16. Ministry of the Environment and Protection of Land and Sea. Piano Nazionale di Adattamento ai Cambiamenti Climatici; Bozza 2017 sottoposta a consultazione; MEPLS: Rome, Italy, 2017.

17. Bruneniece, I.; Klavins, M. Normative Principles for Adaptation to Climate Change Policy Design and Governance. In Climate Change Governance; Knieling, J., Leal Filho, W., Eds.; Springer: Berlin/Heidelberg, Germany, 2013; pp. 41-65. ISBN 978-3-642-29831-8.

18. Hurlimann, A.C.; March, A.P. The role of spatial planning in adapting to climate change. Wiley Interdiscip. Rev. Clim. Chang. 2012, 3, 477-488. [CrossRef]

19. Davoudi, S.; Crawford, J.; Mehmood, A. Climate Change and Spatial Planning Responses. In Planning for Climate Change: Strategies for Mitigation and Adaptation for Spatial Planners; Davoudi, S., Crawford, J., Mehmood, A., Eds.; Routledge: London, UK; Sterling, VA, USA, 2009; pp. 7-18. ISBN 978-1-84407-662-8.

20. Wilson, E. Developing UK spatial planning policy to respond to climate change. J. Environ. Policy Plan. 2006, 8, 9-26. [CrossRef]

21. Gaugitsch, R.; Neugebauer, W.; Böhme, K.; Gaugitsch, R. Spatial Planning and Governance within EU Policies and Legislation and Their Relevance to the New Urban Agenda; European Union: Brussels, Belgium, 2018.

22. Lukat, E.; Tröltzsch, J.; Cazzola, G.; Kiresiewa, Z.; Blobel, D.; Terenzi, A.; Peleikis, J.; Latinos, V.; Purdy, R.; Hjerp, P. Regional and Local Adaptation in the EU since the Adoption of the EU Adaptation Strategy in 2013; Committee of the Regions: Bruxelles, Belgium, 2016; ISBN 978-92-895-0906-0.

23. De Montis, A.; Ledda, A.; Di Cesare, E.A.; Trogu, D.; Campagna, M.; Cocco, G.; Satta, G. Governance and adaptation to climate change: An investigation in Sardinia. In Environmental and Territorial Modelling for Planning and Design; Leone, A., Gargiulo, C., Eds.; FedOAPress: Naples, Italy, 2018; ISBN 978-88-6887-048-5.

24. Larsson, G. Spatial Planning Systems in Western Europe: An Overview; IOS Press: Amsterdam, The Netherlands; Washington, DC, USA, 2006; ISBN 978-1-58603-656-0.

25. Gabellini, P. Tecniche Urbanistiche; Carocci: Roma, Italy, 2001; ISBN 978-88-430-1869-7. 
26. Mercandino, A. Urbanistica Tecnica. Pianificazione Generale, 1st ed.; Il Sole 24 Ore: Milano, Italy, 2008; ISBN 978-88-324-6187-9.

27. Selicato, F.; Rotondo, F. Progettazione Urbanistica-Teorie e Tecniche; Mondadori: Milano, Italy, 2009; ISBN 978-88-386-6547-9.

28. Gaeta, L.; Rivolin, U.J.; Mazza, L. Governo del Territorio e Pianificazione Spaziale; CittàStudi: Novara, Italy, 2013; ISBN 978-88-251-7382-6.

29. De Montis, A. Pianificare il Paesaggio Rurale. Un Manuale [Rural Landscape Planning. A Handbook]; Centro Stampa-Università di Sassari: Sassari, Italy, 2017; ISBN 978-88-907678-4-5.

30. ARS-Autonomous Region of Sardinia. Piano Paesaggistico Regionale. Available online: http://www. sardegnaterritorio.it/pianificazione/pianopaesaggistico/ (accessed on 11 April 2020).

31. European Union. European Landscape Convention-Florence, 20/10/2000-Treaty Open for Signature by the Member States of the Council of Europe and for Accession by the European Union and the European Non-Member States. In European Landscape Convention Treaty No.176; European Union: Brussels, Belgium, 2000.

32. De Montis, A. Impacts of the European Landscape Convention on national planning systems: A comparative investigation of six case studies. Landsc. Urban Plan. 2014, 124, 53-65. [CrossRef]

33. De Montis, A. Measuring the performance of planning: The conformance of Italian landscape planning practices with the European Landscape Convention. Eur. Plan. Stud. 2016, 24, 1727-1745. [CrossRef]

34. Wilson, E.; Piper, J. Spatial Planning and Climate Change, 1st ed.; Routledge: Milton Park, Abingdon, Oxon; New York, NY, USA, 2010; ISBN 978-0-415-49591-2.

35. Fröhlich, J.; Knieling, J. Conceptualising Climate Change Governance. In Climate Change Governance; Knieling, J., Leal Filho, W., Eds.; Springer: Berlin/Heidelberg, Germany, 2013; pp. 9-26. ISBN 978-3-642-29831-8.

36. Biesbroek, G.R.; Swart, R.J.; van der Knaap, W.G.M. The mitigation-adaptation dichotomy and the role of spatial planning. Habitat Int. 2009, 33, 230-237. [CrossRef]

37. Gill, S.; Handley, J.; Ennos, R.; Nolan, P. Planning for Green Infrastructure: Adapting to Climate Change. In Planning for Climate Change; Davoudi, S., Crawford, J., Mehmood, A., Eds.; Earthscan: London, UK, 2009; pp. 249-261. ISBN 978-1-84407-662-8.

38. ARS-Autonomous Region of Sardinia. Piano Stralcio per l'Assetto Idrogeologico. Available online: https:

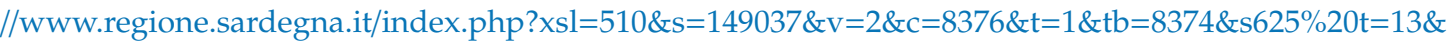
slu=1 (accessed on 11 April 2020).

39. ARS-Autonomous Region of Sardinia. Riesame e Aggiornamento del Piano di Gestione del Distretto Idrografico della Sardegna. Available online: $h t t p: / / w w w . r e g i o n e . s a r d e g n a . i t / i n d e x . p h p ? x s l=510 \& s=304398 \&$ $\mathrm{v}=2 \& \mathrm{c}=6703 \& \mathrm{t}=1 \& \mathrm{tb}=6695 \& \mathrm{st} 631 \% 20=7$ (accessed on 11 April 2020).

40. ARS-Autonomous Region of Sardinia. Piano d'Azione Ambientale Regionale 2009-2013. Available online: https://portal.sardegnasira.it/paar (accessed on 11 April 2020).

41. ARS-Autonomous Region of Sardinia. Piano di Gestione Rischio Alluvioni. Available online: https://www. regione.sardegna.it/j/v/2420?s=1\&v=9\&c=94070\&es=6603\&na=1\&n=10\&esp=1\&t634\%20b=14006 (accessed on 11 April 2020).

42. ARS-Autonomous Region of Sardinia. Piano Regionale della Mobilità Ciclistica della Sardegna. Available online: https://www.regione.sardegna.it/index.php?xsl=2425\&s=386900\&v=2\&c=156\&t=1\&tb=13769 (accessed on 11 April 2020).

43. Cash, D.W.; Clark, W.C.; Alcock, F.; Dickson, N.M.; Eckley, N.; Guston, D.H.; Jäger, J.; Mitchell, R.B. Knowledge systems for sustainable development. Proc. Nat. Acad. Sci. USA 2003, 100, 8086-8091. [CrossRef] [PubMed]

44. Hoppe, R.; Wesselink, A. Comparing the role of boundary organizations in the governance of climate change in three EU member states. Environ. Sci. Policy 2014, 44, 73-85. [CrossRef]

45. Wende, W.; Bond, A.; Bobylev, N.; Stratmann, L. Climate change mitigation and adaptation in strategic environmental assessment. Environ. Impact Assess. Rev. 2012, 32, 88-93. [CrossRef]

46. De Montis, A.; Di Cesare, E.A.; Ledda, A.; Trogu, D.; Campagna, M.; Cocco, G.; Satta, G.; Marcus, A. Integrating climate change adaptation and spatial planning: An assessment for Sardinia, Italy. In Environmental and Territorial Modelling for Planning and Design; Leone, A., Gargiulo, C., Eds.; FedOAPress: Naples, Italy, 2018; ISBN 978-88-6887-048-5. 
47. Lioubimtseva, E.; da Cunha, C. Local climate change adaptation plans in the US and France: Comparison and lessons learned in 2007-2017. Urban Clim. 2020, 31, 100577. [CrossRef]

48. Eisenack, K.; Stecker, R. A framework for analyzing climate change adaptations as actions. Mitig. Adapt. Strateg. Glob. Chang. 2012, 17, 243-260. [CrossRef]

49. Donner, S.D.; Kandlikar, M.; Webber, S. Measuring and tracking the flow of climate change adaptation aid to the developing world. Environ. Res. Lett. 2016, 11, 054006. [CrossRef]

50. Ricci, L. Linking adaptive capacity and Peri-Urban features: The findings of a household survey in Dar es Salaam. In Climate Change Vulnerability in Southern African Cities; Springer: Cham, Switzerland, 2014; pp. 89-107. [CrossRef]

51. Dubois, C.; Cloutier, G.; Rynning, M.K.R.; Adolphe, L.; Bonhomme, M. City and building designers, and climate adaptation. Buildings 2016, 6, 28. [CrossRef]

52. Keskitalo, E.C.H. Introduction-Adaptation to climate change in Europe: Theoretical framework and study design. In Developing Adaptation Policy and Practice in Europe: Multi-Level Governance of Climate Change; Keskitalo, E.C.H., Ed.; Springer: Dordrecht, The Netherlands, 2010; pp. 1-38. ISBN 978-90-481-9324-0.

53. Moser, S.C. Whether our levers are long enough and the fulcrum strong? Exploring the soft underbelly of adaptation decisions and actions. In Adapting to Climate Change: Thresholds, Values, Governance; Lorenzoni, I., O’Brien, K.L., Adger, W.N., Eds.; Cambridge University Press: Cambridge, UK, 2009; pp. 313-334. ISBN 978-0-521-76485-8.

54. Wolf, J. Climate Change Adaptation as a Social Process. Adv. Glob. Chang. Res. 2011, 42, 21-32. [CrossRef]

55. Bauer, A.; Steurer, R. Multi-level governance of climate change adaptation through regional partnerships in Canada and England. Geoforum 2014, 51, 121-129. [CrossRef]

56. Juhola, S.; Westerhoff, L. Challenges of adaptation to climate change across multiple scales: A case study of network governance in two European countries. Environ. Sci. Policy 2011, 14, 239-247. [CrossRef]

57. Mees, H.; Driessen, P. A framework for assessing the accountability of local governance arrangements for adaptation to climate change. J. Environ. Plan. Manag. 2019, 62, 671-691. [CrossRef]

58. Italian Civil Protection [Protezione Civile Italiana].-Piano di Protezione Civile [Civil Protection Plans]. Available online: http://www.protezionecivile.gov.it/servizio-nazionale/attivita/prevenzione/pianoprotezione-civile (accessed on 12 April 2020).

59. Chandra, A.; Idrisova, A. Convention on Biological Diversity: A review of national challenges and opportunities for implementation. Biodivers. Conserv. 2011, 20, 3295-3316. [CrossRef]

60. Akhtar-Schuster, M.; Thomas, R.J.; Stringer, L.C.; Chasek, P.; Seely, M. Improving the enabling environment to combat land degradation: Institutional, financial, legal and science-policy challenges and solutions. Land Degrad. Dev. 2011, 22, 299-312. [CrossRef]

61. Italian Republic, D.lgs. n. 152/2006-Testo consolidato [Environmental Code]. Available online: https://www. camera.it/cartellecomuni/leg15/RapportoAttivitaCommissioni/commissioni/allegati/08/08_all_dlgs152_ 2006.htm (accessed on 11 April 2020).

62. Ritzema, H.P.; Stuyt, L.C.P.M. Land drainage strategies to cope with climate change in the Netherlands. Acta Agric. Scand. Sect. B Soil Plant Sci. 2015, 65, 80-92. [CrossRef]

63. Jongman, B. Effective adaptation to rising flood risk. Nat. Commun. 2018, 9, 1-3. [CrossRef] [PubMed]

64. Stagrum, A.E.; Andenæs, E.; Kvande, T.; Lohne, J. Climate Change Adaptation Measures for Buildings-A Scoping Review. Sustainability 2020, 12, 1721. [CrossRef]

65. Reckien, D.; Petkova, E.P. Who is responsible for climate change adaptation? Environ. Res. Lett. 2019, 14, 014010. [CrossRef]

66. ARS-Autonomous Region of Sardinia. Strategia Regionale di Adattamento. Available online: https://portal. sardegnasira.it/strategia-regionale-di-adattamento (accessed on 25 April 2020).

(C) 2020 by the authors. Licensee MDPI, Basel, Switzerland. This article is an open access article distributed under the terms and conditions of the Creative Commons Attribution (CC BY) license (http://creativecommons.org/licenses/by/4.0/). 